\title{
REFER LA BARCELONA DELS BARRIS METROPOLITANS.
}

\author{
David MARTÍNEZ
}

Des del punt de vista urbanístic la ciutat de Barcelona planteja un conjunt de reptes futurs que podrien agrupar-se en tres estratègies o línies d'actuació -reciclar, recosir i reservar- les cuals es projectarien sobre una doble dimensió de barri i metròpoli. El reciclatge urbà és presenta com una acció imprescindible quan ens referim a estructures velles com els cascs antics, els eixos històrics o la millora del parc d'habitatges massiu de l'època del desarrollisme. El recosit urbà apuntaria un conjunt d'actuacions bolcades sobre el completament de les xarxes de transport, els espais nodals propis de les infraestructures, o els àmbits que a escala metropolitana s'han caracteritzat per ser llocs de pas i necessiten revisar la seva potencialitat per articular millor el territori metropolità. La reserva d'alguns espais estratègics tindria objectius, com ara posar en valor els usos productius de les bosses industrials, i el potencial mediambiental i cultural dels grans buits presents a la ciutat consolidada.

\section{Reciclatge urbà, transformació urbana, urbanisme Barcelona.}

\section{REDOING THE BARCELONA METROPOLITAN DISTRICTS.}

From a planning point of view, Barcelona and its surroundings presents a set of future challenges that could be grouped into three action strategies - recycling, sewing and reservation - which are projected onto two dimensions, neighborhood and metropolis. Recycling is presented as a necessary action when it comes to old structures such as Old Town, the historic areas and the improvement and update of mass housing. Repairing would suggest a set of actions focusing on transport networks, nodal areas and infrastructure, as well as metropolitan scale areas that have been places traditionally needing review with great potentialities to improve the articulation of the metropolitan area. Reservation of certain strategic areas has the objective to highlight the productive reuse of old industrial areas, and also revalue cultural and environmental potential of large voids in the consolidated city.

Urban recycling, urban trasformation, Barcelona urbanism. 
Repensar avui Barcelona en clau urbanística implica segurament atendre la triple dimensió física, social i econòmica del seu territori. De quin àmbit parlem i com el caracteritzem? Qui hi viu i com el viu? Amb quines estratègies afrontem un escenari de recursos limitats? Aquest text només pretén ser l'esbós inicial d'una possible estratègia davant d'aquestes preguntes, apuntant alguns valors i algunes qüestions que podrien formar part d'una xarxa per capturar els reptes d'un futur incert.

Després de vàries dècades d'urbanisme intens, Barcelona ha esdevingut un referent mundial en aquest camp. La ciutat és reconeguda arreu per la qualitat del seu espai públic i la bona arquitectura dels seus equipaments, entre altres valors. També ha destacat en les seves polítiques de planificació i preservació d'alguns espais naturals, així com les polítiques de renovació i impuls d'importants espais d'activitat econòmica, com els espais logístics i de transport que es concentren al delta del Llobregat, o el sector 22@ del Poblenou.

En un futur pròxim Barcelona segurament s'ha de pensar en termes grans, en clau metropolitana, i també petits, en clau de barri. Perquè aquesta doble condició de proximitat i distància, en diferents modalitats i intensitats caracteritza el modus vivendi del ciutadà d'avui. La Barcelona gran ocupa un territori densament construït, madur, amb àrees homogènies ben caracteritzades. Partir de la riquesa d'aquest territori, optimitzar els recursos disponibles i seleccionar amb cura les intervencions, s'apunten com a actituds clau per a treballar-hi en un futur.

En aquest text s'utilitzen tres conceptes per a intentar dibuixar possibles camins per afrontar els reptes d'aquesta Barcelona repensada: reciclar, recosir i reservar. Tres idees que comparteixen la disposició de treballar des del passat i la memòria, per assolir el futur d'un territori més eficient i socialment més just.

\section{Reciclar}

El reciclatge urbanístic és una necessitat. De fet es podria afirmar que l'urbanisme és sempre en certa manera una acció de recliclatge on la presència d'allò anterior serveix de suport a la nova realitat. Una ciutat madura com és Barcelona acumula estructures velles i noves, més petites i més grans. Posar en valor allò que ja existeix i treballar a partir de la seva realitat física sembla un punt de partida imprescindible en qualsevol escenari on els recursos s'hagin d'administrar amb la màxima eficàcia. 


\section{Reciclar l'habitatge}

El reciclatge dels edificis d'habitatge planteja un dels reptes més punyents. Barcelona disposa d'un enorme parc residencial edificat a les dècades dels '50 i els '60 amb algunes mancances en la seva formació (fig. 1). Aquest parc s'acumula en bona mesura en barris no centrals dels municipis metropolitans. Cal pensar i dur a terme polítiques massives en relació a un eventual reciclatge d'aquests edificis. Si en les dècades anteriors el repte va ser universalitzar les clavegueres i l'enllumenat, les voreres i el mobiliari urbà, ara el repte és pensar un recorregut per a aquest parc residencial, per tal que no entri en un col-lapse funcional irreversible.

En un escenari amb menys recursos públics disponibles cal pensar que les actuacions de reforma integral de barris seran molt més sel-lectives, només per a casos d'extrema precarietat, i per tant caldrà afinar més en els instruments i els objectius d'un eventual reciclatge massiu en el camp de l'habitatge.

Allargar la vida útil d'aquestes estructures passarà per millorar el seu comportament energètic i les seves condicions d'accessibilitat, la qual cosa ajudarà a millorar la seva habitabilitat i la qualitat de vida dels usuaris. Podem imaginar diverses línies d'actuació que tindran a veure sovint amb la pròpia realitat morfotipològica dels edificis. Així, el reciclatge de blocs

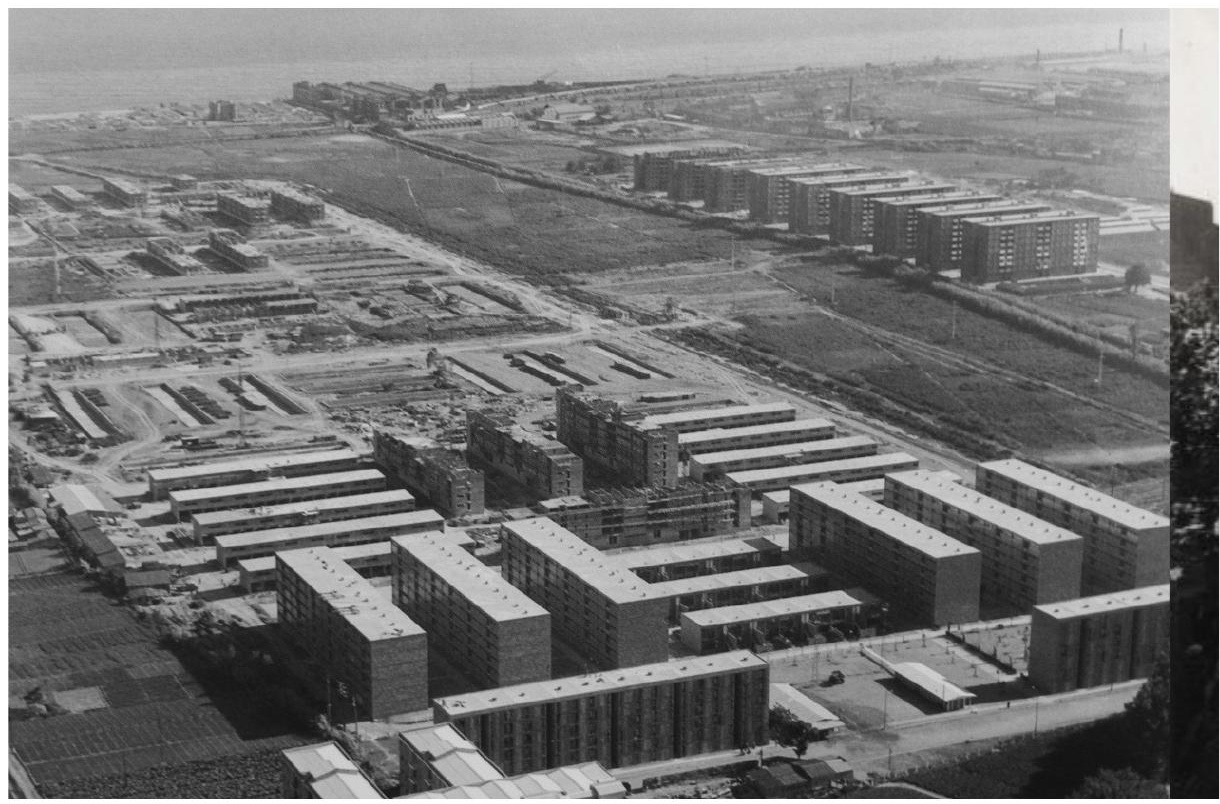

Figura 1: Polígon Sud-oest del Besòs 
d'habitatge en polígons pot comportar un tipus de projecte diferent de la intervenció en edificis entre mitgeres de teixits suburbans, o de sectors de casc antic, per posar-ne alguns exemples.

\section{Reciclar eixos històrics}

Un altre cas de recliclatge seria el que opera al voltant d'eixos i fronts urbans. El decurs de la història ha deixat a Barcelona i els seus entorns elements linials que han acumulat al seu voltant una gran densitat de peces similars, ara en declivi. Descobrir les potencialitats latents d'un antic camí o d'una antiga frontera pot esdevenir una estratègia per rellançar urbanísticament un espai de la ciutat.

A Barcelona, per exemple, l'antic traçat de Pere IV presenta una excel-lent oportunitat per actualitzar la pròpia via, però també les antigues peces industrials que s'hi recolzen, amb usos i activitats renovades. Un altre cas pot ser també el reciclatge del Paral-lel per revitalitzar aquest antic eix cultural i cívic a través de la millora de les condicions urbanes del seu espai físic, procurant-ne una millor relació amb els barris de l'entorn, i potenciant certs usos i activitats per rellançar-lo econòmicament (fig.2).

Un casc especialment rellevant també a Barcelona seria la reformulació del front marítim, on cal millorar les relacions de Ciutat Vella amb el Port

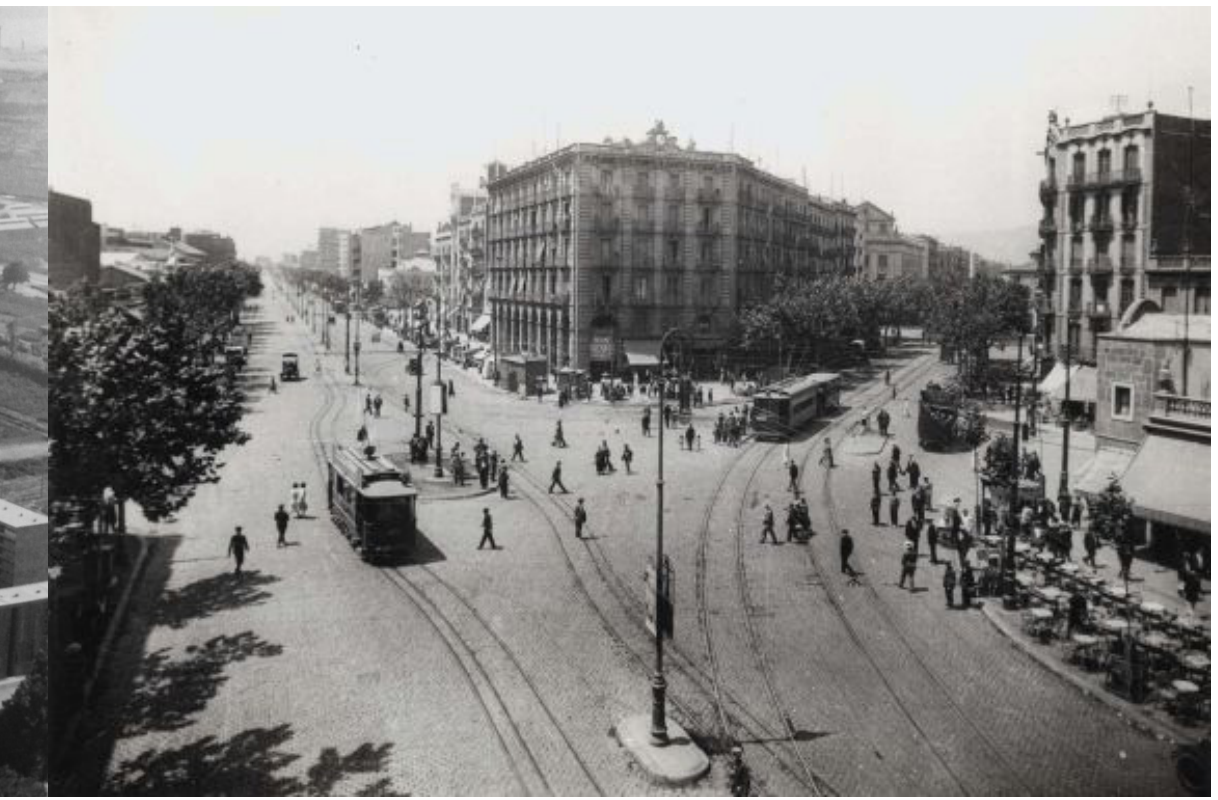

Figura 2: Avinguda Paralılel 
Vell, des de Montjuïc fins a la Barceloneta. En bona part es tractaria de repensar les condicions de mobilitat en tot el sector, tant de les persones com dels vehicles, així com el paper que poden jugar alguns dels edificis existents i altres que eventualment s'hi poguessin edificar per estirar la intensitat urbana del vell districte i fer-la extensiva a tot el Port Vell.

\section{Reciclar els cascs antics}

En aquesta categoria es podria incloure també la intervenció en els fragments de la ciutat més antiga. Barcelona compta amb un conjunt ric de peces urbanes que tenen un valor fonamental en la configuració de referències per a la memòria col-lectiva. Dins del municipi trobem els nuclis antics del Poblenou, Gràcia, Sarrià, Sant Andreu... i a la resta del territori metropolità els centres de poblacions com Badalona, Santa Coloma, Hospitalet, Viladecans, Cornellà...

Aquestes peces han estat des de fa temps objecte d'un tractament específic en la planificació urbanística, tot i que no sempre s'han assolit plenament els objectius perseguits. Sovint encara s'arrosseguen afectacions viàries o corresponents a d'altres sistemes no executades, pensades des d'una lògica més funcional però poc sensible amb les especificitats d'aquests teixits en el moment en què es van plantejar. Caldria una certa actualització d'aquests objectius, cercant un paper més actiu d'aquests centres, compatible amb la seva condició de dipositaris de la memòria històrica.

Un cas específic el constituex el districte de Ciutat Vella de Barcelona. En aquest espai s'acumula la major densitat d'episodis urbans històrics i s'hi produeix la pressió més alta per part del turisme creixent que visita la ciutat. En general en aquestes parts de la ciutat, i a Ciutat Vella en particular, cal proposar estratègies amb l'objectiu de trobar un equilibri entre el seu potencial monumental i turístic, d'una banda, i el caràcter residencial dels seus barris, per tal d'evitar l'expulsió dels veïns i la tendència a convertir-se en un parc temàtic de turisme i serveis.

Caldria pensar doncs en combinar polítiques urbanístiques orientades a millorar la qualitat del parc edificat més antic de l'àrea metropolitana amb estratègies per introduir usos i activitats que mantinguin el pols vital d'aquests espais sense renunciar al seu paper també de barri.

\section{Recosir}

L'acció de recosir suggereix l'existència de peces o situacions pròximes que poden funcionar solidàriament si es facilita la seva sutura. És una acció propera al recliclatge, però molt més selectiva, que no opera sobre àmbits, sinó més aviat sobre sistemes. En aquest tipus d'intervencions és fonamental el coneixement de les peces que s'han d'unir, la seva natura- 
lesa, així com el tipus de conglomerant amb el qual es vol fer efectiva la unió.

\section{Recosir les xarxes de transport}

En la darrera dècada s'ha fet a l'àrea metropolitana de Barcelona un salt importantíssim pel que fa a la cobertura del sistema ferroviari de transport públic de viatgers. S'ha apropat aquest tipus de transport cap a àmbits de la perifèria densament poblats, i s'ha procurat d'aquesta manera un major equilibri territorial dins la metròpoli. La major utilització d'aquests sistemes de transport col-lectiu té dos avantatges clars: la millora del medi ambient a les ciutats i la conquesta progresiva de l'espai viari alliberat pel vehicle privat, que pot destinar-se a altres usos.

Barcelona té ara el repte de completar la seva xarxa de mobilitat per ferla més operativa. De la mateixa manera que les Rondes van significar la superació d'un sistema de trànsit rodat radiocèntric, caldria completar i tancar el mallat de les xarxes de transport col-lectiu, en especial la de metro i tramvia.

El cas paradigmàtic seria la línia 9 del metro, que ha de posar en contacte directe els municipis del Barcelonès Nord amb l'aeroport i la Zona Fran-

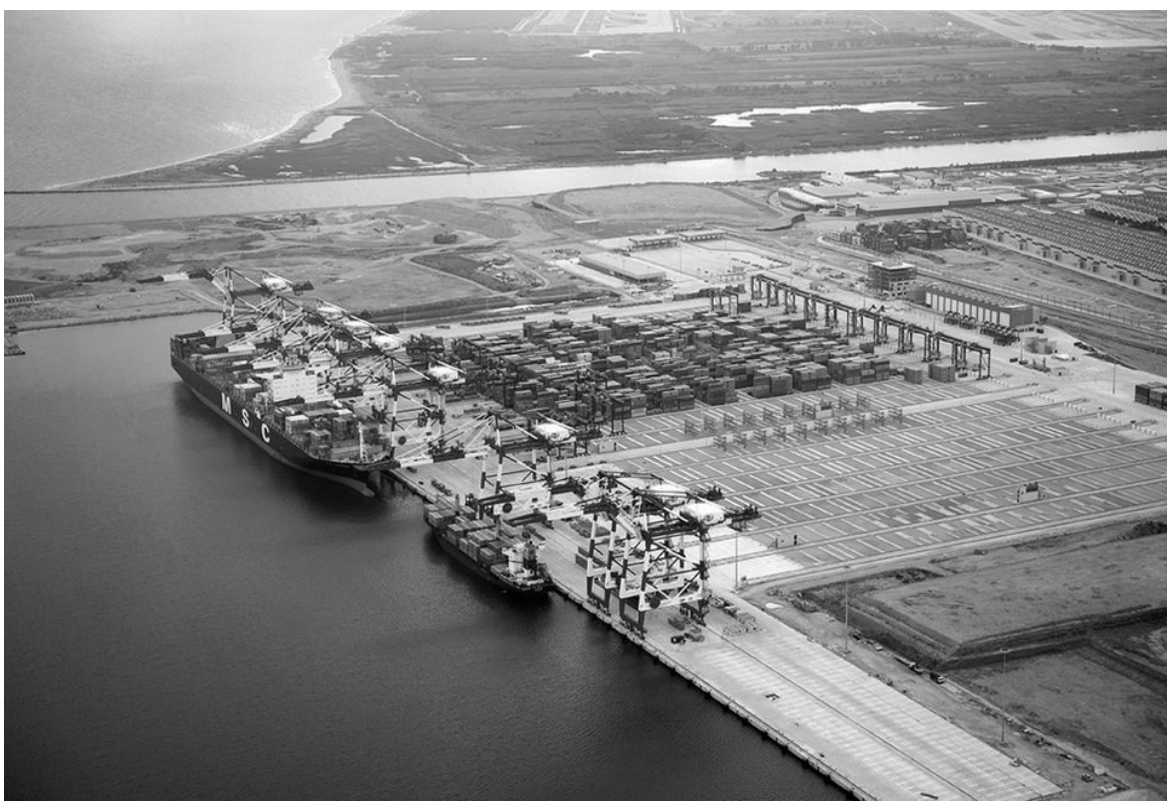

Figura 3: Port de Barcelona 
ca, tot relligant els barris de la primera perifèria barcelonina (Bon Pastor, el Guinardó, Vallcarca...) S'ha completat bona part del traçat, sobretot pels extrems d'aquesta línia, però caldria finalitzar-la. El tram central és bàsic per acabar de mallar el conjunt del sistema, i les prolongacions cap a la Zona Franca i l'aeroport són importants per alimentar bé aquests espais logístics i de transport de la metròpoli.

També ho és recosir el Port amb els sistemes d'infraestructures que el connecten amb Europa i la resta de l'Estat espanyol. La construcció dels accessos definitius viaris i ferroviaris és una inversió pendent i vital per al funcionament i futur creixement previst d'aquesta locomotora de l'economia metropolitana (fig.3).

Finalment, cal considerar el recosit de les dues línies existents de tramvia a Barcelona (el Trambaix i el Trambesòs). Aquesta actuació és clau per millorar l'eficiència de les xarxes existents i d'aquest mode de transport a la ciutat de Barcelona.

\section{Recosir nodes metropolitans}

Una altra categoria serien els recosits puntuals d'emplaçaments concrets localitzats en el territori, que es distingeixen pel seu caràcter nodal. En cada cas cal trobar el gruix adequats dels fils o la combinatòria d'ells, ja que poden concórrer diferents escales en el recosit adequat d'un mateix node. L'interès d'aquest tipus d'intervencions no és només resoldre un tema d'articulació urbana, sinó la capacitat que tenen certs espais per sí mateixos d'esdevenir noves referències i formular nous escenaris per a la vida urbana. A escala metropolitana la configuració d'aquests espais de centralitat ve donada per la seva accessibilitat. Al municipi de Barcelona en trobem tres d'especialment rellevants, amb característiques pròpies que els fan diferents: l'estació de Sants, l'estació de la Sagrera i la plaça de les Glòries.

L'arribada del tren d'alta velocitat a la capital té un impacte molt rellevant, sobretot en les estacions i els seus entorns urbans. Hi ha un predomini de l'escala metropolitana, fins i tot regional i internacional, condicionada per l'extraordinària accessibilitat. Aquests espais de la ciutat esdevenen autèntics rebedors urbans. Són llocs on aparentment el paper d'intercanviador i els fluxes haurien de modelar l'espai físic i determinar-ne la forma. Però també hi ha un conjunt de trames urbanes al voltant d'aquestes grans infraestructures, sovint heterogènies, que cal articular bé. Per tant hi ha un projecte en aquests nodes que té a veure en com es construeix -en el cas de La Sagrera- o com es reconfigura -en el cas de Sants- una estança urbana que respongui alhora a les sol-licitacions dels fluxes i a les característiques pròpies del lloc on s'insereix, configurant 
una nova referència de primer nivell per a la ciutat, sense perdre de vista el seu paper articulador.

En el cas de l'estació de Sants la remodelació i el creixement pendent del propi edifici s'hauria de complementar amb un projecte urbà per als seus entorns, reformulant el tipus d'urbanitat que s'ha de configurar al voltant de l'estació per tal de recosir els barris de Les Corts, Hostafrancs, Sants i l'Eixample. El tema aquí és com s'encaixen les servituds que imposa una infraestructura ja existent, que ha de créixer en un entorn urbà molt consolidat, per tal que no esdevinguin límits i fronteres entre barris. I el contrari, com es pot aprofitar l'activitat i la intensitat que implica el moviment al voltant d'aquest artefacte per fer-ne partíceps els barris colindants.

A la Sagrera el projecte de l'estació no està tant condicionat per l'entorn. La instal.lació és totalment nova i s'encaixa en la construcció d'un entorn

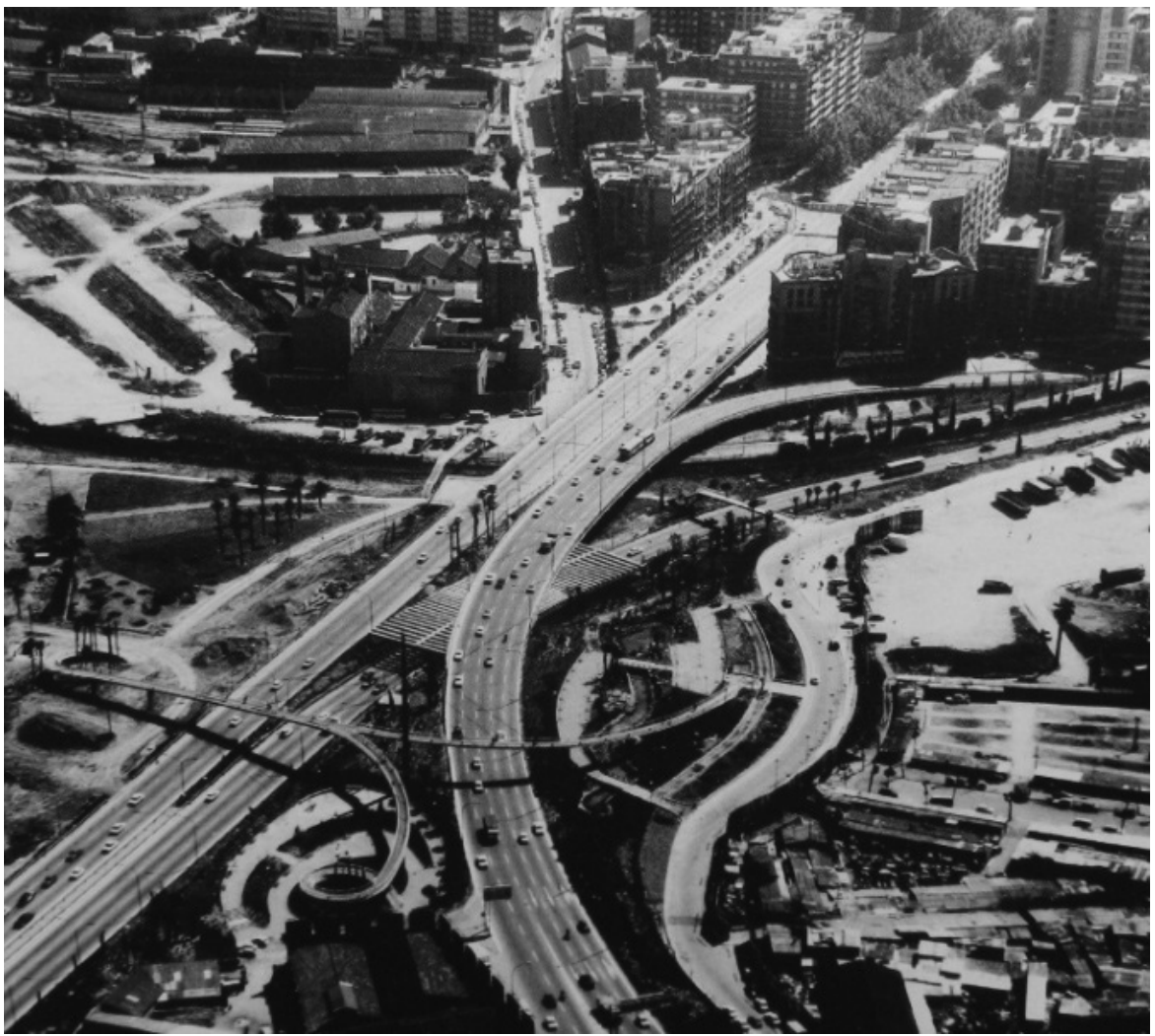

Figura 4: Plaça de les Glòries 
en part també nou, almenys en tota una franja urbana al llarg del traçat ferroriari. En aquest sentit s'han pogut plantejar des del principi les millors opcions per a l'intercanvi de modes de transport (alta velocitat, tren de rodalies, metro, autobús, etc.) El repte en aquest cas consisteix en construir, juntament amb l'estació, un tipus de relació transversal que faciliti el recosit del barri de La Sagrera amb el barri de Sant Martí, històricament separats per les vies del tren.

Un darrer cas emblemàtic a la metròpoli barcelonina és la Plaça de les Glòries, on també cal aplicar bé les puntades per cosir els diversos barris que envolten aquest espai històricament irresolt (fig.4). A diferència dels dos anteriors, en aquest cas no hi ha estació d'alta velocitat, però sí s'interseccionen a diferents nivells línies de ferrocarril i metro, així com vies urbanes i metropolitanes de primer nivell, com ara la Diagonal, la Meridiana i la Gran Via. Després de 150 anys d'haver-se dibuixat l'hora de les Glòries arriba quan el desenvolupament del sector de llevant ha assolit un cert grau de maduresa, amb l'obertura de la Diagonal i la renovació de bona part del districte 22@. És en aquest moment que aquest espai esdevé efectivament central i envoltat de ciutat consolidada. Precisament la discussió sobre què significa centralitat, amb quins usos i activitats, quines arquitectures i a quines distàncies, i quin nivell d'infraestructuració, esdevé el tema més punyent per a la resolució futura d'aquest espai. Més que no pas la quantitat de verd, la uniformitat del perímetre o el soterrament o no de les infraestructures.

En tots aquests casos de nodes lligats a la mobilitat en espais urbans madurs trobem sempre el repte de minimitzar l'impacte de les servituds de la gran infraestructura i alhora fer extensiva l'activitat que aquesta genera per millorar l'apropament de barris que havien quedat separats per aquella mateixa infraestructura, com si d'alguna manera s'estigués saldant un deute històric amb ells.

\section{Recosir territoris intermitjos}

Segurament menys evident però no menys important és el recosit de grans àmbits a escala metropolitana, mitjançant la intervenció en els anomenats territoris intermitjos. Normalment a cavall entre diversos municipis, lloc de pas de les grans infraestructures i habitualment amb la presència de cursos fluvials, aquestes franges de territori sense model reclamen atenció projectual i un paper propi en l'estratègia dels nous espais d'autoafirmació de l'habitant de la metròpoli. Els rius i les vores urbanes són avui paisatges tan habituals per a l'home metropolità com el carrer o la plaça.

A la Barcelona metropolitana hi trobem alguns d'enorme importància, com el territori expectant al voltant del Besòs, entre la futura estació de La Sagrera i el nou port de Badalona. Com a territori de projecte, aquest no es 
limita només al riu i a les seves vores, sinó que abasta un espai d'uns $20 \mathrm{~km} 2$, que va de Montcada i Reixach a Sant Adrià, on hi viu gairebé un milió de persones, que representen més del $10 \%$ de la població de Catalunya i més del 20\% si ens referim a la Regió Metropolitana. Es tracta d'un territori que comparteix la geografia de la conca baixa i el delta del riu, però també una història lligada a la indústria, l'habitatge obrer i les il.lusions d'un riu recuperat que dècades enrere va ser una autèntica claveguera a cel obert. Es tractaria doncs de reforçar el territori del Besòs com a nova centralitat emergent, i això passaria per atendre diversos objectius complementaris de tipus ambiental, social i econòmic.

La recuperació ambiental del riu, que es va dur a terme als anys '90, va permetre'n l'apropiació com a espai públic per part de la ciutadania. A aquest èxit palpable, cal sumar la transformació urbana de molts trams del front marítim i la regeneració de les platges. Des del punt de vista ambiental el repte ara consisteix en reforçar el paper del riu com a eix vertebrador, tot articulant-lo amb les platges i les estribacions de Collserola i la serralada de Marina, per esdevenir un veritable sistema d'espais públics d'abast metropolità.

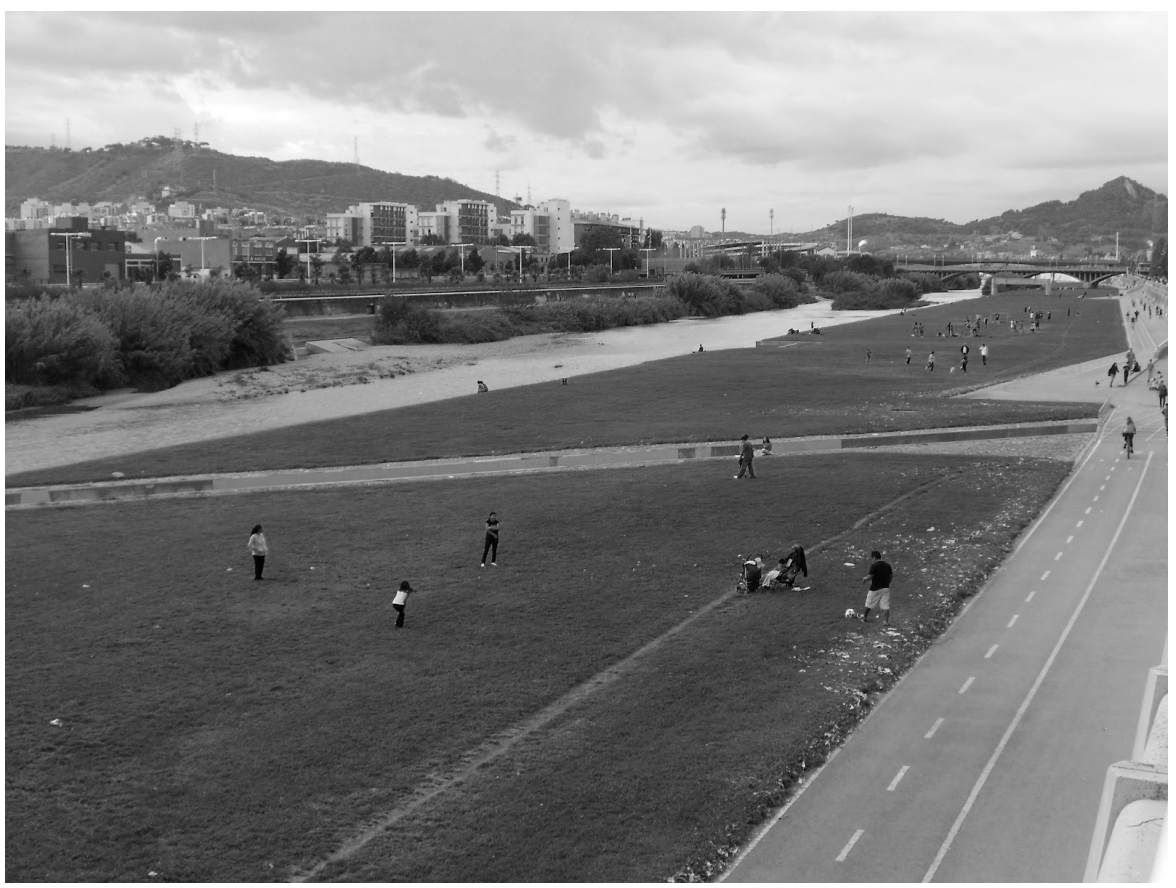

Figura 5: Pont Vell sobre el Besòs 
Més enllà de la millora en la qualitat de vida que suposa la recuperació d'espais lliures i la seva sistematització, cal focalitzar l'atenció en els barris i en la seva transformació física com a motor de la millora social. En aquest sentit cal recordar que pràcticament tots els barris d'aquest ampli territori van rebre durant l'última dècada importants inversions públiques orientades en bona part a millorar-ne l'espai urbà. L'aposta social del projecte del Besòs hauria de suposar sobretot continuar amb l'aposta per millorar la qualitat de vida dels seus barris.

El projecte del Besòs hauria de servir també per enfortir i ampliar els espais d'oportunitat per a les noves economies emergents ja presents en aquest territori lligades al coneixement, el medi ambient, o les energies netes, i reforçar actius ja existents en els camps de la cultura, el lleure i la salut. Des de la perspectiva pública el projecte del Besòs hauria d'actuar fonamentalment en el camp de les infraestructures, amb projectes que permetin adaptar a la lògica urbana elements com autopistes i traçats ferroviaris que en bona part són responsables de la lectura fragmentada i poc unitària que encara tenen d'aquest territori els seus habitants. En paral-lel, caldria millorar també les connexions entre els barris, i això passaria per estructurar una xarxa de vies clara que faci més eficaç la mobilitat en aquest espai de la metròpoli. En aquest punt pot ser clau

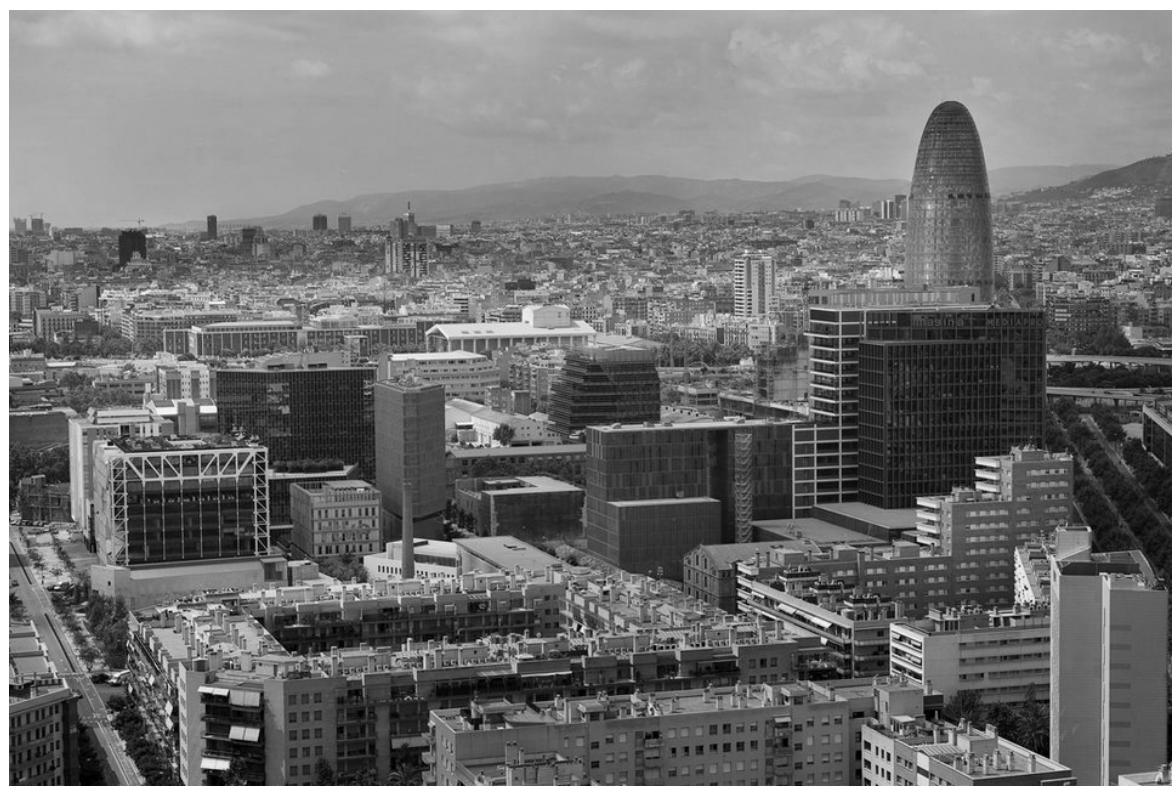

Figura 6: Sector 22@ 
l'actuació sobre els ponts per tal d'enfortir les relacions urbanes a banda i banda del riu (fig. 5).

\section{Reservar}

Una tercera estratègia complementària a les anteriors té a veure amb la consciència de posar límits a la urbanització, entesa com a consum extensiu de sòl, per tal de garantir l'equilibri entre buits i plens al territori metropolità. Reservar sòl per a futures instal-lacions de serveis i estructures públiques i col-lectives és una acció habitual en la planificació urbana. Però més enllà d'aquestes reserves legals, pot ser interessant pensar per a la Barcelona metropolitana algunes grans reserves de diferent tipus i a diferents escales.

\section{Reservar grans bosses industrials}

En entorns urbans centrals ha estat freqüent la trasformació d'espais industrials obsolets, reconvertint-los en molts casos en nous sectors residencials. Aquestes operacions normalment han aportat millores en els seus entorns immediats, en forma de cessions d'espais públics i carrers que la ciutat ha rebut ja urbanitzats, o reserves de sòl per fer-hi nous equipaments. Actuacions que també van provisionar d'habitatge nou a la ciutat consolidada, evitant un major consum de sòl a l'extrarradi.

Atesa la generació de plusvàlues, la multiplicació indiscriminada d'aquestes operacions podria comportar el perill d'eliminar els espais destinats a les activitats productives del nucli central de la metròpoli barcelonina, i la tendència a consolidar un model urbà més simple, de residència i serveis. Amb aquesta visió la ciutat de Barcelona va inventar la singular reconversió de la peça industrial més gran de l'àrea metropolitana en el conegut districte d'activitats 22@, orientat a les noves economies emergents entorn del coneixement.

Actualment existeixen a l'àrea central de la metròpoli grans bosses industrials, com ara les del Bon Pastor, Badalona sud o l'Hospitalet. No es tractaria de copiar literalment el model del 22@, sinó més aviat d'entendre l'estratègia que hi ha darrera, començant pel model de ciutat que allà es proposa: el d'una ciutat diversa que inclou l'activitat econòmica i la producció, en convivència amb la residència, els serveis i el comerç.

Caldria entendre-les com a plens que cal reservar per a resoldre reptes futurs que avui ni coneixem, com en el seu dia es va fer amb el 22@ del Poblenou. Per tant preservar-les de transformacions facils que no aporten valor afegit al territori metropolità. A la vegada caldria garantir unes condicions suficients per tal que s'hi pugui desenvolupar l'activitat industrial amb normalitat, en tant que no s'afronti la transformació integral de la peça concreta. 


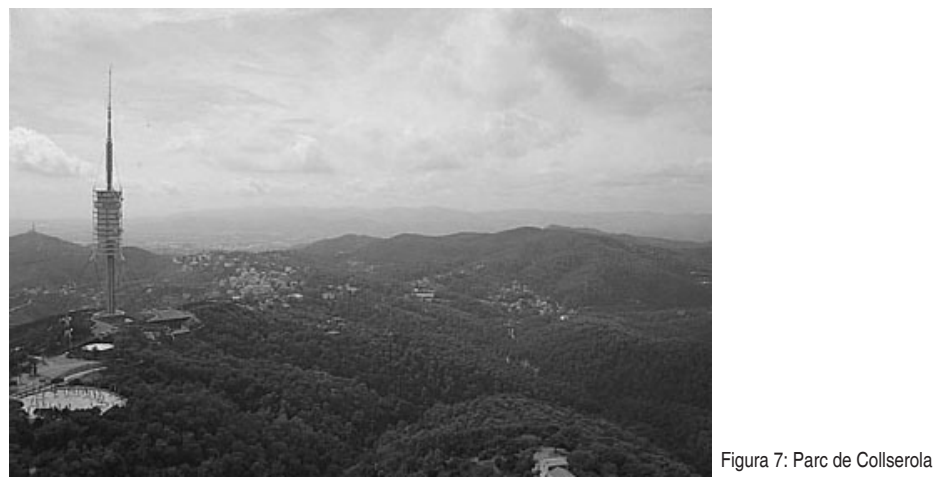

\section{Reservar els grans buits urbans}

En el cas dels grans buits, reservar comporta dotar de contingut i projecte, per tal de preservar aquells àmbits que per les seves característiques no haurien de ser objecte d'urbanització, en el sentit intensiu referit més amunt. La protecció legal és bàsica, però no sembla suficient. Cal reactivar els grans buits urbans i territorials a partir d'accions propositives, d'acord amb les seves vocacions naturals o agrícoles. Des dels Tres Turons de Barcelona, fins a Collserola o el Parc Agrari, passant per Montjuïc, sembla necessari dibuixar nous projectes on el ciutadà metropolità pugui reconèixer els valors lligats al paisatge i el medi ambient. Identitat i equilibri podrien ser dos conceptes per començar-hi a treballar.

El cas dels Tres Turons representa per a Barcelona, amb més de 120 hectàrees, la reserva més gran de parc urbà enmig de la trama urbana. Durant anys la ciutat ha pogut participar i discutir sobre el futur d'aquest emplaçament format pels turons del Carmel, de la Creueta del Coll i de la Rovira, i que també inclou el parc Güell i el parc del Guinardó. Un cop enllestida la planificació d'aquest espai caldrà acometre paulatinament l'execució dels seus elements, començant per l'elaboració del projecte del parc, on s'hauran d'incloure camins i miradors, portes d'entrada i elements d'urbanització. La consolidació del parc s'haurà d'acompanyar amb actuacions puntuals sobre elements viaris i noves dotacions que completin el seu perímetre i que han de millorar els barris que l'envolten (El Carmel, la Font d'en Fargues, el Guinardó, Can Baró, el Coll, Vallcarca i La Salut)

En un sentit diferent la muntanya de Montjuïc també podria compartir aquesta estratègia basada en impulsar el projecte conjunt d'una gran peça urbana per tal de preservar-la. En aquest cas però es tracta d'un recinte en bona part consolidat per a usos de ciutat, tant dels seus equipaments com dels seus espais lliures. Les actuacions a Montjuïc hauran de buscar un 
equilibri entre els diferents components que caracteritzen aquest espai. Com a mínim hi ha quatre aspectes que caldrà considerar: la utilització i l'estat dels equipaments, els valors mediambientals i naturals, la relació amb els barris que l'envolten i el tractament de les vores, així com els temes d'accessibilitat i mobilitat.

Però sens dubte la gran reserva a nivell metropolità és el Parc de Collserola, el gran buit urbà de prop de 10.000 hectàrees situat entre Barcelona, el Vallès, i els rius Llobregat i Besòs (fig. 7). Aquesta peça va ser declarada Parc Natural amb l'objectiu de conservar els seus valors naturals i evitar els efectes negatius de la pressió urbanística, tot potenciant les activitats econòmiques i socials que s'hi desenvolupen. En paral.lel a la gestió ordinària del parc, caldrà elaborar un projecte i el document urbanístic que reguli el conjunt.

Aquesta mateixa estratègia es podria fer extensiva a les altres grans reserves naturals de l'àrea metropolitana, com ara el massís del Garraf o la Serralada de Marina. Sobre aquests espais cal elaborar projectes que posin en valor el seus patrimonis naturals i culturals, que fomentin les actuacions per millorar-ne l'ús social i les activitats econòmiques compatibles amb el seu caràcter. També cal afrontar la qüestió de com es relacionen aquestes reserves amb les urbs que les envolten. Aquest treball hauria de fer-se primer des d'una lectura atenta als valors d'aquests buits urbans i arribar després a una proposta d'estructura que permeti relacionar-los correctament amb les ciutats.

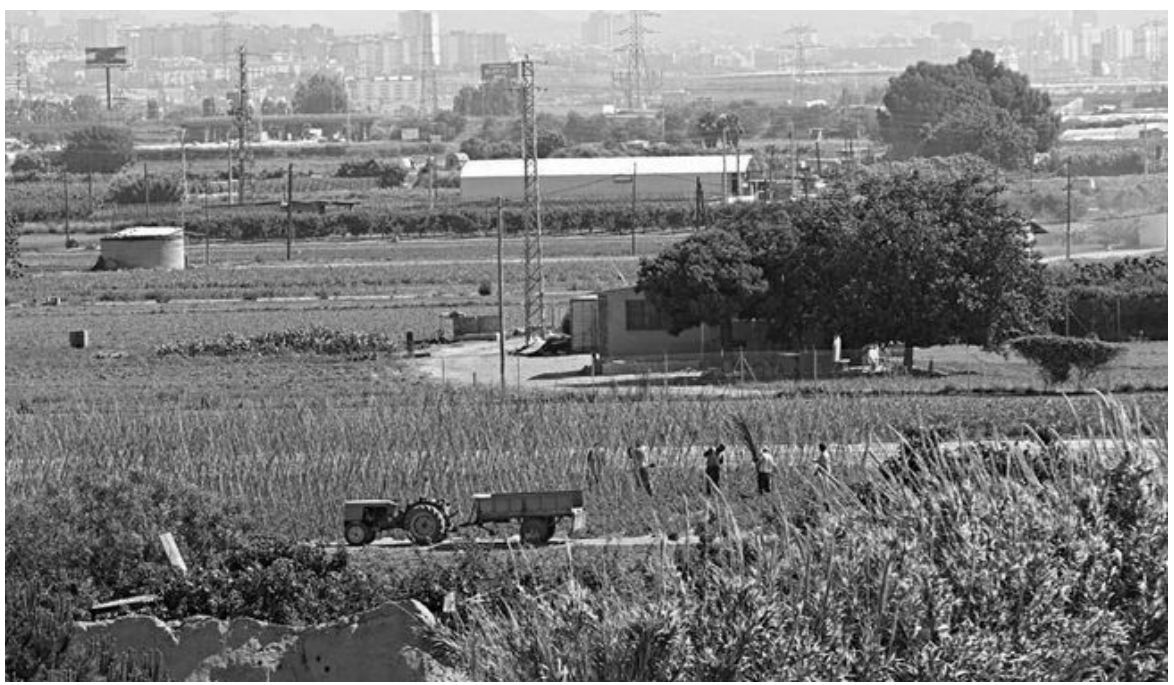

Figura 8: Parc Agrari del Baix Llobregat 
Una darrera peça per completar aquest mosaic de grans buits urbans a l'àrea metropolitana de Barcelona seria el Parc agrari del Baix Llobregat. De naturalesa ben diferent a les anteriors, la figura del parc agrari correspon a una estratègia per preservar els espais agrícoles periurbans de la pressió urbanística dels seus entorns. En aquest cas es tracta d'un territori que per les seves carácterístiques topogràfiques i la seva proximitat a Barcelona i a les seves principals infraestructures ha estat lloc de pas dels principals traçats viaris, ferroviaris i altres serveis pel costat sud i de ponent de la capital. La construcció d'infraestructures i els diferents creixements urbans han anat trinxant i minvant en superfície aquest espai agrícola. Davant de futures pressions per a urbanitzar aquest delicat espai, cal refermar un projecte propi, basat en els valors paisatgístics i culturals, fent valer el seu potencial econòmic lligat a l'activitat agrària i les seves vocacions com a espai de lleure i d'ús social (fig. 8).

\section{Conclusió}

Amb els conceptes reciclar, recosir i reservar, s'ha volgut en aquest text iniciar el dibuix d'un possible camí per tornar a pensar urbanísticament Barcelona. L'acció de reciclar es refereix als assentaments i les estructures urbanes que en major o menor mesura han entrat en declivi o que poden millorar-se clarament per allargar-ne la vida útil. A la vegada el funcionament d'aquestes estructures podria ser més eficient si pensem en recosir els diferents sistemes que les alimenten, i per tant operant en les diferents infraestructures i sistemes ecològics, i que les noves funcions que se'ls assigni es tradueixin també en la creació de nous espais col-lectius i formes d'expressió urbana. Finalment, la millor eficiència de la ciutat existent hauria de servir per reservar els espais estratègics i els de major valor ambiental, necessaris per a l'equilibri de la vida metropolitana, preservant-los del consum de sòl facil, tot incorporant-los plenament a l'ús col-lectiu amb un projecte propi.

Totes tres accions s'apliquen sobre elements d'abast metropolità, ja que aquesta escala de reflexió ha d'estar indiscutiblement present en un territori on bona part de les relacions urbanes hi tenen a veure. Però a la vegada sembla clar que les intervencions a escala metropolitana tindran una incidència molt clara a escala de barri, i per tant una gran influència en el funcionament futur dels assentaments de l'entorn. Aquest diàleg entre barri i metròpoli, sumat a la triple estratègia apuntada, serien en síntesi les coordenades proposades per refer la Barcelona del futur. 


\section{Referències Bibliogràfiques:}

BUSQUETS, Joan. Barcelona: evolución urbanística de una capital compacta. Madrid: Mapfre, 1992

Pla especial de protecció i millora del Parc Agrari del Baix Llobregat, Consorci Parc Agrari del Baix Llobregat, Barcelona, 2003

Collserola : el parc metropolità de Barcelona : intervencions 1983-2008, Barcelona: Consorci Parc de Collserola, 2008

Barcelona, transformació: Plans i projectes, Barcelona: Ajuntament de Barcelona, 2008

El Pla Territorial Metropolità de Barcelona. Revista Papers núm. 55. Barcelona: Institut d'Estudis Regionals i Metropolitans de Barcelona, 2012.

Pla Besòs, enfortint una centralitat metropolitana emergent. Barcelona: Oficina Tècnica del Besòs (Barcelona Regional), 2011 